\title{
Synthesis of Water Soluble Analogs of Arylsulfonylimidazolidinone (JSH-2282)
}

\author{
Seong-Cheol Bang, Ki-Cheul Lee, Vinay K. Sharma, Niti Sharma, Hyun-Sun Yang, and Sang-Hun Jung* \\ College of Pharmacy and Institute of Drug Research and Development, Chungnam National University, Daejeon 305-764, Korea \\ *E-mail: jungshh@cnu.ac.kr \\ Received February 6, 2013, Accepted April 8, 2013
}

\begin{abstract}
To improve the water solubility of arylsulfonylimidazolidinone (JSH-2282), a potent anti-cancer agent, two urea derivatives, sodium $(S)-2-(3-(4-(5-((S)-2-o x o-4-p h e n y l i m i d a z o l i d i n-1-y l s u l f o n y l) i n d o l i n e-1-c a r b o n y l)-$ phenyl)ureido)succinate (2a) and sodium $(S)-2-(3-(4-(5-((S)-2-o x o-4-p h e n y l i m i d a z o l i d i n-1-y l s u l f o n y l) i n d o-$ line-1-carbonyl)phenyl)ureido)pentanedioate (2b), were synthesized and studied for solubility and anti-cancer activity.
\end{abstract}

Key Words : Arylsulfonylimidazolidinone, Solubility, Cytotoxicity, Anti-cancer

\section{Introduction}

Ever since the discovery of anti-cancer drugs, antimitotic agents such as vinca alkaloids, vinblastine and vincristine, as well as the taxanes (taxol and taxotere) have been recognized as effective medicine for the treatment of variety of cancers. ${ }^{1,2}$ However, the mechanism of action and clinical use of all these antimitotic agents are associated with the problems of drug resistance, toxicity and poor bioavailability. ${ }^{3}$ Therefore, nontoxic anti-cancer drug with increased bioavailability and selectivity is required to make safer medicine.

Previously, we have discovered a novel and promising anti-cancer candidate, JSH-2282 ((4S)-1-[1-(4-aminobenzoyl)-2,3-dihydro- $1 H$-indol-6-sulfonyl]-4-phenylimidazolidin2-one, Fig. 1), ${ }^{4}$ which not only showed the potent antitumor in vitro activity but also proved its worth in the in vivo test by exhibiting approximately $45 \%, 42 \%$, and $94 \%$ suppression of tumor growth against murine colon adenocarcinoma (colon 26), Lewis lung carcinoma (3LL), and human colon cancer (SW620) at a dose of $65 \mathrm{mg} / \mathrm{kg}$ (p.o., $\mathrm{q} 2 \mathrm{~d} \times 5)$, respectively. Unexpectedly, in the preclinical trials on beagle dog the drug was accumulated in the intestinal wall causing toxicity despite of the good therapeutic potential. This could be due to the poor solubility $(0.0235 \mathrm{mg} / \mathrm{mL})$ of JSH-2282 in water. Thus, its solubility has been identified as a critical parameter in preclinical trials. Therefore, we shifted our focus to improve the water solubility of JSH-2282. It has been reported that introduction of an ionizable moiety into the structure of the compound is one of the common approaches to improve the water solubility. ${ }^{5-9}$ In that context we observed that the structure of JSH-2282 has two plausible sites which can be connected with a linker, one is a nucleophilic amide (Site 1 in Fig. 1) of heterocyclic imidazolidin-2-one, and the other is a basic aromatic amine (Site 2 in Fig. 1) attached at $1 H$-indoline. The preliminary studies revealed that Site 1 was more restricted to the structure manipulations compared to Site 2 in terms of the activity (not published). Thus we decided to investigate modifications at Site 2 . Therefore, we synthesized two newly designed analogs $\mathbf{2 a}$ and $\mathbf{2 b}$ of JSH-2282 with amino acid moieties as illustrated in Figure 1, which would allow ionization or salt formation.

\section{Results and Discussion}

Compounds $\mathbf{2 a}$ and $\mathbf{2 b}$ were designed by linking with urea function of $\mathbf{1}$ with L-aspartic acid and L-glutamic acid moieties, respectively, to improve the water solubility (Fig. 1). In case of L-glutamic acid, we anticipated the facilitation of drug bioavailability in vivo, because L-glutamic acid is a key intermediate in the biosynthesis of other amino acids by a process known as transamination. ${ }^{10}$

Syntheses of compounds $\mathbf{2}$ were performed as outlined in
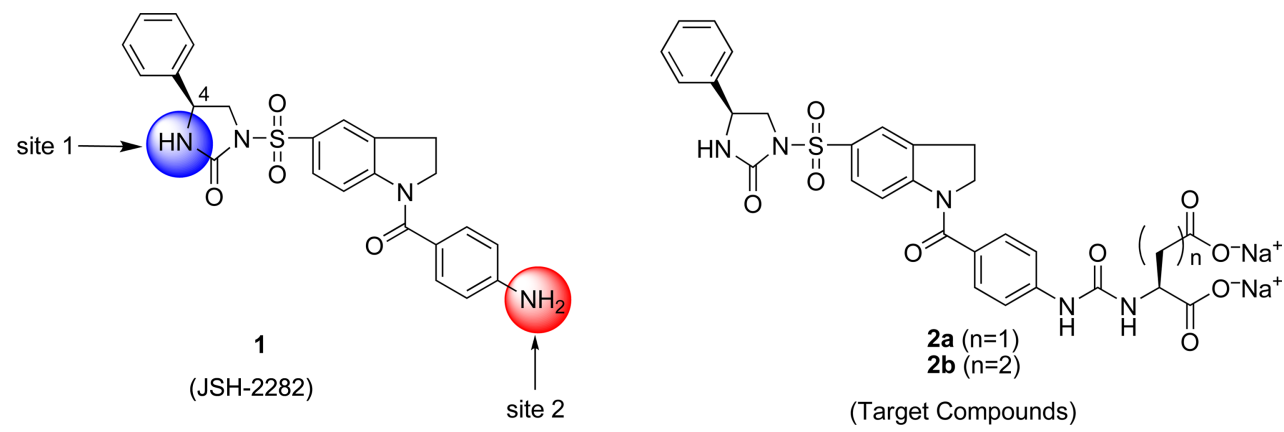

Figure 1. JSH-2282 (1) and Target compounds (2a and 2b). 


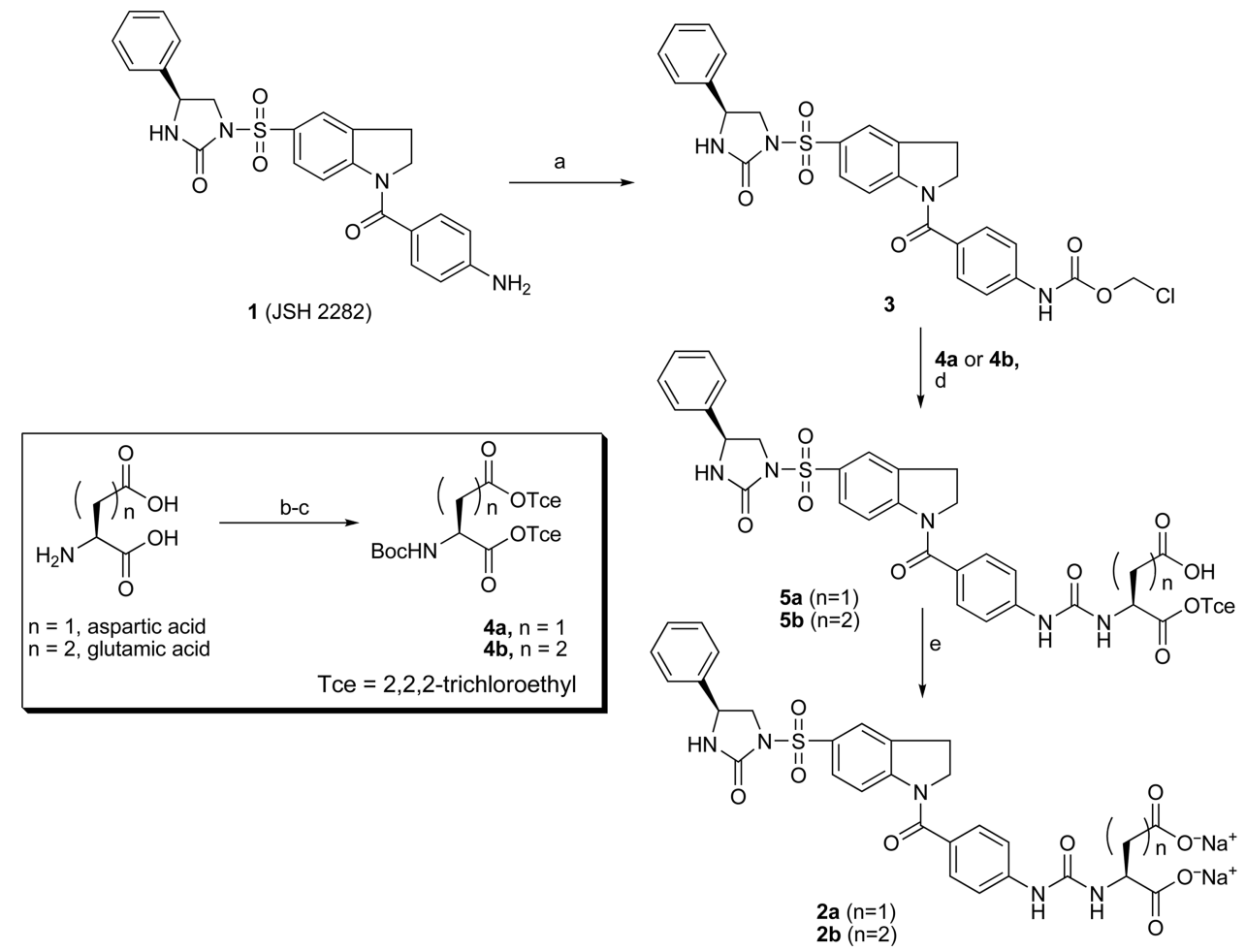

Reagents and conditions: (a) chloromethyl chloroformate, TEA, THF, $0{ }^{\circ} \mathrm{C}$ - rt, 12 h, 35-41\%; (b) di-tert-butyl dicarbonate, NaOH, dioxane/ $\mathrm{H}_{2} \mathrm{O}$, rt, $18 \mathrm{~h}$; (c) 2,2,2-trichloroethanol, DCC, DMAP, $\mathrm{CH}_{2} \mathrm{Cl}_{2}, 0{ }^{\circ} \mathrm{C}$ - rt, $24 \mathrm{~h}, 49 \%$ for $\mathbf{4 a}$ and $69 \%$ for $\mathbf{4 b}$ in two steps; (d) TFA/CH (1:1), rt, $1 \mathrm{~h}$, and then TEA, DMF, $0{ }^{\circ} \mathrm{C}-\mathrm{rt}, 24 \mathrm{~h}, 58 \%$ for $\mathbf{5 a}$ and $39 \%$ for $\mathbf{5 b}$ in two steps; (e) $\mathrm{NaHCO}_{3}, \mathrm{THF} / \mathrm{H}_{2} \mathrm{O}(2: 1), 0{ }^{\circ} \mathrm{C}-\mathrm{rt}, 24 \mathrm{~h}, 76 \%$ for $\mathbf{2 a}$ and $61 \%$ for $\mathbf{2 b}$.

Scheme 1. Synthesis of $\mathbf{2 a}$ and $\mathbf{2 b}$.

Scheme 1. Accordingly, amino acids are protected with 2,2,2-trichloroethyl (Tce) ester group in order to exclude the possibility of intramolecular cyclization in the reaction process ${ }^{11}$ as well as in order to make the easy removal of the introduced protecting groups. The suitable fully-protected compound 4a (BocNH-Asp(OTce)-OTce) and 4b (BocNHGlu(OTce)-OTce) were synthesized from L-aspartic acid and L-glutamic acid in two steps (49\% and 69\% yield, respectively). Treatment of compound 4a (BocNH-Asp(OTce)OTce) or $\mathbf{4 b}$ (BocNH-Glu(OTce)-OTce) with trifluoroacetic acid gave de-Boc intermediate in situ and then chloromethoxycarbonyl compound $\mathbf{3}$ in the presence of TEA was added and stirred at $0{ }^{\circ} \mathrm{C}$ for $24 \mathrm{~h}$ to produce the urea intermediates $\mathbf{5 a}$ or $\mathbf{5} \mathbf{b}$, which possesses one free carboxylic acid. In these reactions, it is also possible to form a $\mathrm{S}_{\mathrm{N}} 2$ substitution product. However ${ }^{1} \mathrm{H}-\mathrm{NMR}$ spectra confirmed that the $\mathrm{CH}_{2}$ peak of aminomethoxyl $\left(-\mathrm{C}(\mathrm{O}) \mathrm{O}-\mathrm{CH}_{2}-\mathrm{NH}-\right)$ did not appear and only one of $\mathrm{CH}_{2}$ peak (4.82 ppm, s, $2 \mathrm{H}$ for $\mathbf{5 a}$ and $4.79 \mathrm{ppm}, \mathrm{s}, 2 \mathrm{H}$ for $\mathbf{5 b}$, respectively) for 2,2,2trichloroethyl appeared. MS data were matched with compound $\mathbf{5 a}$ and $\mathbf{5 b}$. Thus formation of urea rather than substitution was confirmed in this reaction. The proposed mechanism for the formation of compounds $\mathbf{5 a}$ or $\mathbf{5 b}$ is illustrated in Figure 2 and we hypothesized that these compounds may be formed through heterocyclic intermediate 4,5-dihydro-1,3-oxazin-6-one after formation of urea. Finally, the target sodium salt compounds $\mathbf{2 a}$ and $\mathbf{2 b}$ were obtained via base hydrolysis from urea products $\mathbf{5 a}$ and $\mathbf{5 b}$, respectively.

The obtained urea derivatives $\mathbf{2 a}$ and $\mathbf{2 b}$ were initially tested for their water solubility in distilled water. ${ }^{12}$ The solubility of $\mathbf{2 a}(9.714 \mathrm{mg} / \mathrm{mL})$ and $\mathbf{2 b}(14.880 \mathrm{mg} / \mathrm{mL})$ was increased remarkably over 400 times compared to that of JSH-2282 $(<0.0235 \mathrm{mg} / \mathrm{mL})$. These results indicate that the obtained urea derivatives are successful in improving the solubility. As the compounds $\mathbf{2 a}$ and $\mathbf{2 b}$ showed far better

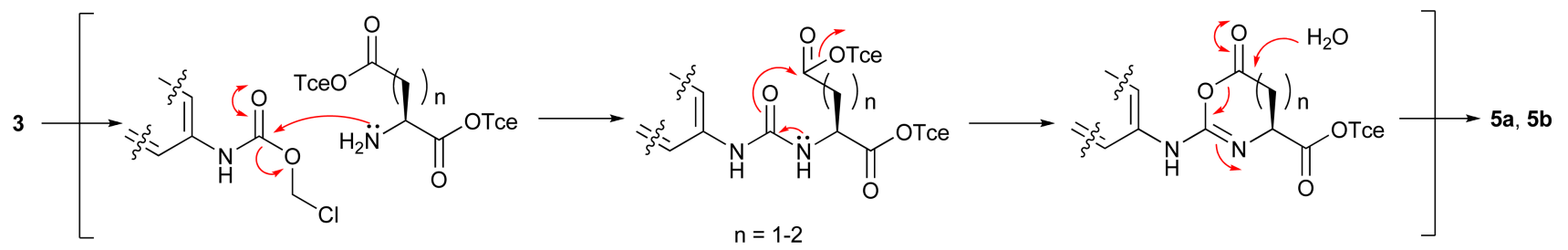

Figure 2. A possible mechanism for formation of compound $\mathbf{5} \mathbf{a}$ and $\mathbf{5 b}$. 
solubility, their cytotoxicity was investigated against SW620 cell lines. Surprisingly, the cytotoxicity of $2 \mathbf{a}\left(\mathrm{IC}_{50}=\right.$ $5.46 \mu \mathrm{M})$ and $\mathbf{2 b}\left(\mathrm{IC}_{50}=10.89 \mu \mathrm{M}\right)$ against SW-620 cell line was far less as compared to that of JSH-2282 $\left(\mathrm{IC}_{50}<0.39\right.$ $\mu \mathrm{M})$. The above results confirmed one of the previous finding that the ionized form has low lipid solubility but high water solubility (i.e. hydrophilicity) and thus cannot penetrate the cell membrane easily which may lead to lower cytotoxicity. ${ }^{13}$

Since urea linkage is possibly cleaved in plasma to generate JSH-2282, reconversion tests with these compounds in rat plasma under in vitro and in vivo conditions were performed but JSH-2282 was not formed until $8 \mathrm{~h}$ in both the conditions. Thus these tests confirmed that compounds 2a and $\mathbf{2 b}$ are very stable and the cytotoxicity obtained is purely due to $\mathbf{2 a}$ and $\mathbf{2 b}$ and not because of the parent compound JSH-2282.

\section{Conclusion}

Two water soluble analogs $\mathbf{2 a}$ and $\mathbf{2 b}$ of arylsulfonylimidazolidinone (JSH-2282) were prepared by conjugating an amino acid (L-aspartic acid or L-glutamic acid) using urea linkage and studied for the solubility and anti-cancer activity. The newly discovered compounds showed significant stability both under in vitro as well as in vivo system and remarkably improved water solubility compared to the parent compound. However, relatively low cytotoxicity hampered the in vivo anti-cancer study. Therefore, further elaboration for finding the other analogs with better pharmacological activity is in progress.

\section{Experimental}

Chemistry. All reagents and solvents were dried prior to use according to the standard methods. Commercial reagents were used without further purification unless otherwise stated. Melting points were measured on an Electrothermal melting point apparatus. IR spectra were obtained on $\mathrm{KBr}$ disks using a JASCO Report 100 spectrophotometer. ${ }^{1} \mathrm{H}$ NMR spectra were recorded on JNM-AL 400 (Jeol) instrument operating at $400 \mathrm{MHz}$ and the chemical shift $(\delta)$ were reported in parts per million downfield from tetramethylsilane (TMS). Electro spray mass spectra (ESIMS) were recorded on PE SCIEX API 2000 (triple quadrupole) LCMS/MS system (Applied Biosystems, Foster City, CA, USA). Chromatographic separations were performed on silica gel columns by flash (Kieselgel 40, 0.040-0.063 mm; Merck) or gravity column (Kieselgel 60, 0.063-0.200 mm; Merck). The reactions were followed by thin-layer chromatography (TLC) on Merck glass silica gel (Kiesel gel $60 \mathrm{~F}_{254}$ ) plates that were visualized under a UV lamp. HPLC was performed using a Shimadzu liquid chromatograph model Class-vp version 6.12, equipped with a SPD-10A UV-vis detector (Shimadzu). The HPLC analysis was performed using a Symetry $\mathrm{TM}^{\circledR} \mathrm{C}$ 18 column $(3.9 \times 150 \mathrm{~mm}$, Part No. WAT054205, Waters, Milford, MA). The elution condition was a linear gradient of
$31-95 \%$ acetonitrile in $0.1 \%$ TFA for $30 \mathrm{~min}$ at a flow rate of $1 \mathrm{~mL} / \mathrm{min}$ with UV detection at $254 \mathrm{~nm}$. All solvents for HPLC were filtered through a $0.45 \mu \mathrm{m}$ membrane filter (Waters, USA).

General Synthetic Procedure for Compounds 2a and 2b (Scheme 1).

Synthesis of (S)-Chloromethyl 4-(5-(2-oxo-4-Phenylimidazolidin-1-yl-sulfonyl)indoline-1-carbonyl) Phenyl Carbamate (3): Under $\mathrm{N}_{2}$, a solution of 1 (JSH-2282, 300 $\mathrm{mg}, 0.61 \mathrm{mmol})$ and TEA $(260 \mu \mathrm{L}, 3 \mathrm{eq})$ in dry THF $(10$ $\mathrm{mL}$ ) was stirred in ice bath for $0.5 \mathrm{~h}$, and then chloromethyl chloroformate ( $82 \mu \mathrm{L}, 1.5 \mathrm{eq})$ in dry THF $(5 \mathrm{~mL})$ was added. After continuous stirring for another $12 \mathrm{~h}$, the reaction mixture was quenched by $50 \mathrm{~mL}$ of diluted water. It was taken up with EtOAc $(100 \mathrm{~mL} \times 3)$ and its organic layer was sequentially washed with saturated aqueous $\mathrm{NaHCO}_{3}$ solution $(50 \mathrm{~mL} \times 2)$, brine $(50 \mathrm{~mL} \times 2)$ and water $(100 \mathrm{~mL}$ $\times 2$ ). The organic layer was dried with anhydrous $\mathrm{Na}_{2} \mathrm{SO}_{4}$ and was then evaporated under reduced pressure to give a crude solid, which was purified by column chromatography using the Hexane-EtOAc $(3: 1 \rightarrow 1: 1)$ as eluent to give 3 (120 mg, 35.4\%) as a pale yellow solid.

${ }^{1} \mathrm{H}-\mathrm{NMR}\left(400 \mathrm{MHz}, \mathrm{CDCl}_{3}\right) \delta 7.91(\mathrm{~s}, 1 \mathrm{H}), 7.78(\mathrm{~m}, 2 \mathrm{H})$, $7.60-7.53(\mathrm{~m}, 4 \mathrm{H}), 7.37(\mathrm{~d}, J=6.4 \mathrm{~Hz}, 3 \mathrm{H}), 7.25(\mathrm{~d}, J=3.2$ $\mathrm{Hz}, 2 \mathrm{H}), 5.84(\mathrm{~s}, 2 \mathrm{H}), 4.78(\mathrm{t}, J=7.6 \mathrm{~Hz}, 1 \mathrm{H}), 4.31(\mathrm{t}, J=$ $9.2 \mathrm{~Hz}, 1 \mathrm{H}), 4.18(\mathrm{t}, J=8.4 \mathrm{~Hz}, 2 \mathrm{H}), 3.69(\mathrm{dd}, J=9.6,7.2$ $\mathrm{Hz}, 1 \mathrm{H}), 3.19$ (t, $J=8.4 \mathrm{~Hz}, 2 \mathrm{H})$; IR $\left(\mathrm{cm}^{-1}, \mathrm{KBr}\right) 3300$, 1730, 1560; ESIMS: $m / z=556.0[\mathrm{M}+1]^{+}$.

Synthesis of BocNH-Asp(OTce)-OTce (4a): To a solution of L-aspartic acid $(1.0 \mathrm{~g}, 7.51 \mathrm{mmol})$ in dioxane $/ \mathrm{H}_{2} \mathrm{O}$ $(1: 1,40 \mathrm{~mL}) \mathrm{NaOH}$ was added $(1.2 \mathrm{~g}, 4 \mathrm{eq})$. The reaction mixture was stirred at room temperature for $0.5 \mathrm{~h}$, and then cooled to $0{ }^{\circ} \mathrm{C}$ (ice bath). To the cooled reaction mixture $(\mathrm{Boc})_{2} \mathrm{O}(2.5 \mathrm{~g}, 1.5 \mathrm{eq})$ was added and allowed to warm up to room temperature and further stirred for $18 \mathrm{~h}$. After completion of the reaction, the mixture was diluted with water $(200 \mathrm{~mL})$ and titrated to $\mathrm{pH} 3-4$ with $1 \mathrm{~N} \mathrm{HCl}$. The aqueous solution was extracted with EtOAc $(100 \mathrm{~mL} \times 3)$ and the EtOAc layers were all combined. The organic layer was washed with brine $(100 \mathrm{~mL} \times 2)$, water $(100 \mathrm{~mL} \times 2)$, and then evaporated in vacuo. The given BocNH-Asp-OH as colorless syrup was directly used in the next step.

The BocNH-Asp-OH was dissolved in dry $\mathrm{CH}_{2} \mathrm{Cl}_{2}(100$ $\mathrm{mL}$ ) and the reaction mixture was cooled to $0{ }^{\circ} \mathrm{C}$, and then 2,2,2-trichloroethanol (1.1 mL, $2.4 \mathrm{eq})$, DCC (2.2 g, $2.4 \mathrm{eq})$, and DMAP (290 $\mathrm{mg}, 0.5 \mathrm{eq}$ ) was sequentially added and the mixture was stirred for $24 \mathrm{~h}$ under $\mathrm{N}_{2}$. The insoluble urea was removed by filtering through celite aid, and the filtrate was diluted with EtOAc $200 \mathrm{~mL}$ and washed with saturated $\mathrm{NaHCO}_{3}(50 \mathrm{~mL} \times 2)$, brine $(50 \mathrm{~mL} \times 2)$, and water $(100 \mathrm{~mL}$ $\times 2$ ). The organic layer was dried with anhydrous $\mathrm{Na}_{2} \mathrm{SO}_{4}$ and then evaporated in vacuo. The residue was purified by a Si gel column chromatography using the Hexane-EtOAc (5 : 1) as eluent to give compound $4 \mathrm{a}$ ( $1.815 \mathrm{~g}, 49 \%$ for two steps) as a colorless syrup.

${ }^{1} \mathrm{H}-\mathrm{NMR}\left(400 \mathrm{MHz}, \mathrm{CDCl}_{3}\right) \delta 4.81$ (s, 2H), $4.76(\mathrm{~s}, 2 \mathrm{H})$, $4.13(\mathrm{~m}, 1 \mathrm{H}), 3.25$ (dd, $J=17.6,4.8 \mathrm{~Hz}, 1 \mathrm{H}), 3.10(\mathrm{dd}, J=$ 
$17.4,4.8 \mathrm{~Hz}, 1 \mathrm{H}), 1.46$ (s, 9H).

Synthesis of BocNH-Glu(OTce)-OTce (4b): The procedure for the preparation of $\mathbf{4 a}$ was applied for the synthesis of compound $\mathbf{4 b}$ with L-glutamic acid $(1.0 \mathrm{~g}, 6.8 \mathrm{mmol})$ as a starting material to give pure $\mathbf{4 b}(810 \mathrm{mg}, 68.8 \%$ for two steps) as a colorless syrup.

${ }^{1} \mathrm{H}-\mathrm{NMR}\left(400 \mathrm{MHz}, \mathrm{CDCl}_{3}\right) \delta 4.76(\mathrm{~s}, 2 \mathrm{H}), 4.75(\mathrm{~s}, 2 \mathrm{H})$, $4.53(\mathrm{~m}, 1 \mathrm{H}), 2.68-2.62(\mathrm{~m}, 2 \mathrm{H}), 2.83(\mathrm{~m}, 1 \mathrm{H}), 2.08(\mathrm{~m}, 1 \mathrm{H})$, $1.45(\mathrm{~s}, 9 \mathrm{H})$.

Synthesis of (S)-4-0xo-3-(3-(4-(5-((S)-2-oxo-4-phenylimidazolidin-1-ylsulfonyl)indoline-1-carbonyl)phenyl)ureido)4-(2,2,2-trichloroethoxy)butanoic acid (5a): TFA (5 mL) was added to a stirred solution of BocNH-Asp(OTce)-OTce (4a, $53 \mathrm{mg}, 0.11 \mathrm{mmol})$ in $\mathrm{CH}_{2} \mathrm{Cl}_{2}(5 \mathrm{~mL})$. The reaction mixture was stirred at room temperature for $1 \mathrm{~h}$. Volatile compounds in the reaction mixture were removed under reduced pressure. The residue was triturated and washed with anhydrous $\mathrm{Et}_{2} \mathrm{O}$, and then the solid was isolated by decantation. The solid H-Asp(OTce)-OTce was dried under vacuum to remove the residual $\mathrm{Et}_{2} \mathrm{O}$ and was used in the next step without further purification.

Under $\mathrm{N}_{2}$, to a cooled $\left(0^{\circ} \mathrm{C}\right)$ stirred solution of compound H-Asp(OTce)-OTce in dry DMF $(10 \mathrm{~mL})$ was slowly added TEA (38 $\mu \mathrm{L}, 3 \mathrm{eq})$ and dropwise added a solution of compound $3(50 \mathrm{mg}, 0.09 \mathrm{mmol})$ in dry DMF $(10 \mathrm{~mL})$. The reaction mixture was stirred at $0{ }^{\circ} \mathrm{C}$ for $1 \mathrm{~h}$ and then at ambient temperature for $24 \mathrm{~h}$. The reaction mixture was diluted with water $(50 \mathrm{~mL})$ and extracted EtOAc $(50 \mathrm{~mL} \times$ $3)$. The combined organic layer was washed successively with saturated $\mathrm{NaHCO}_{3}(50 \mathrm{~mL} \times 2)$, brine $(50 \mathrm{~mL} \times 2)$, and water $(100 \mathrm{~mL} \times 2)$. The organic layer was dried with anhydrous $\mathrm{Na}_{2} \mathrm{SO}_{4}$ and evaporated in vacuo. The residue was purified by a Si gel column chromatography using the $c \mathrm{Hx}: \mathrm{EtOAc}=1: 4 \rightarrow 1: 5$ as eluent to give compound 5a (40 $\mathrm{mg}, 58 \%)$ as a pale yellow solid.

${ }^{1} \mathrm{H}-\mathrm{NMR}\left(400 \mathrm{MHz}, \mathrm{CDCl}_{3}\right) \delta 7.90(\mathrm{~s}, 1 \mathrm{H}), 7.81(\mathrm{~m}, 2 \mathrm{H})$, $7.64(\mathrm{dd}, J=27.2,8.4 \mathrm{~Hz}, 4 \mathrm{H}), 7.36(\mathrm{~d}, J=6.8 \mathrm{~Hz}, 3 \mathrm{H}), 7.24$ (d, $J=8.0 \mathrm{~Hz}, 2 \mathrm{H}), 4.82(\mathrm{~s}, 2 \mathrm{H}), 4.77(\mathrm{t}, J=7.6 \mathrm{~Hz}, 1 \mathrm{H})$, $4.57(\mathrm{~m}, 1 \mathrm{H}), 4.29(\mathrm{t}, J=9.0 \mathrm{~Hz}, 1 \mathrm{H}), 4.17(\mathrm{t}, J=8.8 \mathrm{~Hz}$, 2H), 3.67 (dd, $J=8.0,7.2 \mathrm{~Hz}, 1 \mathrm{H}$ ), 3.29 (dd, $J=17.6,3.2$ $\mathrm{Hz}, 1 \mathrm{H}), 3.19$ (t, $J=8.4 \mathrm{~Hz}, 2 \mathrm{H}), 3.04(\mathrm{dd}, J=17.6,8.4 \mathrm{~Hz}$, $1 \mathrm{H})$; IR $\left(\mathrm{cm}^{-1}, \mathrm{KBr}\right) 3300,1720,1650,1170,760$; ESIMS: $m / z=754.0[\mathrm{M}+1]^{+}$.

Synthesis of (S)-5-Oxo-4-(3-(4-(5-((S)-2-0xo-4-phenylimidazolidin-1-ylsulfonyl)indoline-1-carbonyl)phenyl)ureido)5-(2,2,2-trichloroethoxy)pentanoic acid (5b): The procedure for the preparation of $\mathbf{5 a}$ was applied for the synthesis of compound $\mathbf{5 b}$ with BocNH-Glu(OTce)-OTce $(\mathbf{4 b}, 383$ $\mathrm{mg}, 0.75 \mathrm{mmol})$ as a starting material to give pure $\mathbf{5 b}(153$ $\mathrm{mg}, 40 \%$ ) as a pale yellow solid.

${ }^{1} \mathrm{H}-\mathrm{NMR}\left(400 \mathrm{MHz}, \mathrm{CDCl}_{3}\right) \delta 7.92(\mathrm{~s}, 1 \mathrm{H}), 7.81(\mathrm{~d}, \mathrm{br}, J$ $=8.0 \mathrm{~Hz}, 2 \mathrm{H}), 7.64(\mathrm{dd}, J=28.8,8.4 \mathrm{~Hz}, 4 \mathrm{H}), 7.37(\mathrm{~d}, J=$ $6.8 \mathrm{~Hz}, 3 \mathrm{H}), 7.25(\mathrm{~d}, J=8.4 \mathrm{~Hz}, 2 \mathrm{H}), 4.79(\mathrm{~s}, 2 \mathrm{H}), 4.77(\mathrm{t}, J$ $=7.6 \mathrm{~Hz}, 1 \mathrm{H}), 4.36(\mathrm{t}, J=6.4 \mathrm{~Hz}, 1 \mathrm{H}), 4.31(\mathrm{t}, J=9.2 \mathrm{~Hz}$, $1 \mathrm{H}), 4.16$ (t, $J=8.0 \mathrm{~Hz}, 2 \mathrm{H}), 3.69$ (dd, $J=9.4,7.2 \mathrm{~Hz}, 1 \mathrm{H}$ ), $3.20(\mathrm{t}, J=8.4 \mathrm{~Hz}, 2 \mathrm{H}), 2.76(\mathrm{t}, J=7.2 \mathrm{~Hz}, 2 \mathrm{H}), 2.46-2.36$ (m, 1H), 2.31-2.24 (m, 1H); IR ( $\left.\mathrm{cm}^{-1}, \mathrm{KBr}\right) 3310,1720$,
1650, 1180, 1100, 760; ESIMS: $m / z=768.0[\mathrm{M}+1]^{+}$.

Synthesis of Sodium (S)-2-(3-(4-(5-((S)-2-Oxo-4-phenylimidazolidin-1-ylsulfonyl)indoline-1-carbonyl) phenyl)ureido) succinate (2a): To a solution of compound 5a (186 $\mathrm{mg}, 0.247 \mathrm{mmol})$ in $\mathrm{THF} / \mathrm{H}_{2} \mathrm{O}(2: 1,22.5 \mathrm{~mL})$ was added $\mathrm{NaHCO}_{3}(46 \mathrm{mg}, 2.2 \mathrm{eq})$ and stirred at $0{ }^{\circ} \mathrm{C}$ for $24 \mathrm{~h}$. The reaction mixture was concentrated at $40{ }^{\circ} \mathrm{C}$ under vacuum. The residue was triturated and washed with anhydrous $\mathrm{Et}_{2} \mathrm{O}$ $(5 \mathrm{~mL} \times 3)$, and then the solid was isolated by decantation. The solid was again recrystallized with a cooled solution of acetone and ether, to give the desired compound 2a (144 mg, $76 \%$ ) as a white amorphous solid.

${ }^{1} \mathrm{H}-\mathrm{NMR}\left(400 \mathrm{MHz}, \mathrm{CD}_{3} \mathrm{OD}\right) \delta 7.84(\mathrm{~s}, 1 \mathrm{H}), 7.76$ (s, br, 2H), $7.54(\mathrm{~s}, \mathrm{br}, 4 \mathrm{H}), 7.34-7.30(\mathrm{~m}, 3 \mathrm{H}), 7.24(\mathrm{~d}, J=8.0 \mathrm{~Hz}$, $2 \mathrm{H}), 4.78(\mathrm{dd}, J=8.8,6.0 \mathrm{~Hz}, 1 \mathrm{H}), 4.53(\mathrm{t}, J=6.0 \mathrm{~Hz}, 1 \mathrm{H})$, $4.31(\mathrm{t}, J=9.4 \mathrm{~Hz}, 1 \mathrm{H}), 4.21(\mathrm{t}, J=8.0 \mathrm{~Hz}, 2 \mathrm{H}), 3.60(\mathrm{dd}, J$ $=9.6,6.0 \mathrm{~Hz}, 1 \mathrm{H}), 3.19(\mathrm{~m}, 2 \mathrm{H}), 2.83(\mathrm{dd}, J=11.2,5.2 \mathrm{~Hz}$, $2 \mathrm{H})$; IR $\left(\mathrm{cm}^{-1}, \mathrm{KBr}\right) 3300,1710,1650,760$; ESIMS: $\mathrm{m} / z=$ $622.6[\mathrm{M}+1]^{+}$.

Synthesis of Sodium $(S)-2-(3-(4-(5-((S)-2-O x 0-4-p h e n y l-$ imidazolidin-1-ylsulfonyl)indoline-1-carbonyl) phenyl)ureido) pentanedioate (2b): The procedure for the synthesis of compound $\mathbf{2 b}$ from compound $\mathbf{5 b}(63 \mathrm{mg}, 0.08$ mmol) was similar to that used for compound 2a. The compound $\mathbf{2 b}$ (33 mg, 61\%) was obtained as a white solid.

${ }^{1} \mathrm{H}-\mathrm{NMR}\left(400 \mathrm{MHz}, \mathrm{CD}_{3} \mathrm{OD}\right) \delta 7.86(\mathrm{~s}, 1 \mathrm{H}), 7.82(\mathrm{~d}, \mathrm{br}$, 2H), $7.67(\mathrm{dd}, J=52.0,8.4 \mathrm{~Hz}, 4 \mathrm{H}), 7.36-7.31(\mathrm{~m}, 3 \mathrm{H}), 7.21$ $(\mathrm{dd}, J=8.0,2.0 \mathrm{~Hz}, 2 \mathrm{H}), 4.79(\mathrm{dd}, J=8.6,6.4 \mathrm{~Hz}, 1 \mathrm{H})$, $4.34-4.29(\mathrm{~m}, 2 \mathrm{H}), 4.19$ (t, $J=8.4 \mathrm{~Hz}, 2 \mathrm{H}), 3.60(\mathrm{dd}, J=9.2$, $2.8 \mathrm{~Hz}, 1 \mathrm{H}), 3.24(\mathrm{t}, J=9.4 \mathrm{~Hz}, 2 \mathrm{H}), 2.36-2.34(\mathrm{~m}, 2 \mathrm{H}), 2.03$ (m, br, 2H); IR ( $\left.\mathrm{cm}^{-1}, \mathrm{KBr}\right) 3310,1725,1650,1180,1120$, 760; ESIMS: $m / z=636.6[\mathrm{M}+1]^{+}$.

Water Solubility. JSH-2282 and analogs $\mathbf{2 a}$ and $\mathbf{2 b}$ were saturated in distilled water and shaken vigorously. The saturated solutions were sonicated for $30 \mathrm{~min}$ at $25^{\circ} \mathrm{C}$ and passed through a syringe filter (Cellulose acetate $0.45 \mu \mathrm{m}$ filter unit, DISMIC-13cp, Advantec). The concentrations of the filtrates were analyzed using reverse phase HPLC (RPHPLC).

In Vitro Plasma Reconversion Kinetics Studies. Plasma was obtained from the purchased Male Sprague-Dawley rats. The stock solution $(1 \mathrm{mg} / \mathrm{mL})$ of compound $\mathbf{2 a}$ and $\mathbf{2 b}$ in dimethylsulfoxide (DMSO) was again diluted 100 times with the plasma and the mixture was maintained at $37 \pm 0.5$ ${ }^{\circ} \mathrm{C}$ by a Precision shaking water bath. No plasma protein precipitation was observed at this concentration of DMSO. The plasma was sampled at selected times $(0 \mathrm{~h}, 1 \mathrm{~h}, 2 \mathrm{~h}, 4 \mathrm{~h}$, and $8 \mathrm{~h}$ ), and then it was later subjected to the sample preparation method described below and then analyzed with the modified HPLC assay (Table 1).

Sample Preparation. Plasma samples $(40 \mu \mathrm{L})$ were diluted with a sufficient volume $(3 \mathrm{~mL})$ of methylene chloride to precipitate the plasma proteins as well as to extract the compounds of interest. After vortex mixing for $5 \mathrm{~min}$ and centrifuging at $3000 \mathrm{~g}$ for $10 \mathrm{~min}$, the organic layer was carefully taken out and dried. The plasma extracts were reconstituted in $160 \mu \mathrm{L}$ of methanol with vortexing. After 
Table 1. The water solubility and cytotoxicity of $\mathbf{2 a}$ and $\mathbf{2} \mathbf{b}$ against SW620 and results of reconversion test (in vitro, in vivo)

\begin{tabular}{ccccccccc}
\hline \multirow{2}{*}{ Compound } & \multirow{2}{*}{$\begin{array}{c}\text { Solubility } \\
(\mathrm{mg} / \mathrm{mL})\end{array}$} & $\begin{array}{c}\mathrm{IC}_{50}(\mu \mathrm{M}) \\
(\mathrm{SW620})\end{array}$ & \multicolumn{5}{c}{ Reconversion test $(\mathrm{h})^{b, c}$} \\
\cline { 5 - 9 } & & 0 & 1 & 2 & 4 & 8 \\
\hline $\mathbf{2 a}$ & 9.7140 & 5.46 & $\mathrm{X}$ & $\mathrm{X}$ & $\mathrm{X}$ & $\mathrm{X}$ & $\mathrm{X}$ \\
$\mathbf{2 b}$ & 14.880 & 10.89 & $\mathrm{X}$ & $\mathrm{X}$ & $\mathrm{X}$ & $\mathrm{X}$ & $\mathrm{X}$ \\
$\mathbf{1}(\mathrm{JSH}-2282)$ & 0.0235 & 0.39 & & & & & \\
\hline
\end{tabular}

${ }^{a}$ SW620 is human colorectal adenocarcinoma cell line. ${ }^{b, c} \mathrm{Yes}(\mathrm{O})$ or No $(\mathrm{X})$ on the detection of JSH-2282 under the above described HPLC condition on assigned time ( $0 \mathrm{~h}-8 \mathrm{~h})$ in vitro rat plasma as well as in vivo.

syringe filtration $(0.45 \mu \mathrm{m}$, Waters $)$, the filtrate was analyzed using RPHPLC.

In Vivo Kinetics Reconversion Studies Using Rats.

Animals: Male Sprague-Dawley rats, about 7 weeks old, were obtained from Nippon SLC Co. Ltd. (Hamamatsu, Japan). The rats were housed under controlled environmental conditions and fed commercial feed pellets. All rats had free access to food and water.

In Vivo Kinetics Reconversion: Five male SpragueDawley rats weighing 240-300 g were fasted overnight with free access to water for at least $12 \mathrm{~h}$. A jugular vein cannula was equipped to sample systemic blood. At $30 \mathrm{~min}$ before drug administration, $250 \mu \mathrm{L}$ of the blank blood sample was removed via cannula. Doses of the compound $\mathbf{2 a}$ and $\mathbf{2 b}$ were freshly prepared as saline solution immediately before administration. The administered volume of drugs was 1 $\mathrm{mg} / \mathrm{kg} / \mathrm{mL}$. Compound $\mathbf{2 a}$ and $\mathbf{2 b}$ were administered intravenously, and then systemic blood was sampled via a jugular vein cannula $(250 \mu \mathrm{L})$ at selected times $(0 \mathrm{~min}, 15 \mathrm{~min}, 30$ $\mathrm{min}, 60 \mathrm{~min}, 120 \mathrm{~min}, 240 \mathrm{~min}$, and $480 \mathrm{~min}$ ) after dosing. Blood samples were kept on ice, heparinized, and centrifuged, then the plasma was immediately stored at $-80{ }^{\circ} \mathrm{C}$ until analysis by RP-HPLC. The plasma samples were combined with $700 \mu \mathrm{L}$ of ethyl acetate, vortexed vigorously for $5 \mathrm{~min}$, and shaken for $1 \mathrm{~h}$ at room temperature followed by centrifugation at $2500 \mathrm{x}$ g for $15 \mathrm{~min}$. The organic layer $(550 \mu \mathrm{L})$ was evaporated to dryness using a rotary evapo- rator (SC100, Savant), and then samples were reconstituted in $60 \mu \mathrm{L}$ of methanol with vortexing. After syringe filtration $(0.45 \mu \mathrm{m}$, Waters $)$, the filtrate was analyzed using RPHPLC.

Bioassay. The cytotoxicity of JSH-2282, compounds 2a and $\mathbf{2 b}$ was measured using the SRB assay described previously against SW-620 cancer cell lines. ${ }^{14}$ Doxorubicin was used as the positive control. The results are shown in Table 1.

Acknowledgments. This research was supported by Basic Science Research Program through the National Research Foundation of Korea (NRF) funded by the Ministry of Education (2009-0093815).

\section{References}

1. Jordan, M. A.; Wilson, L. Nat. Rev. Cancer 2004, 4, 253.

2. Jordan, A.; Hadfield, J. A.; Lawrence, N. J.; McGown, A. T. Med. Res. Rev. 1998, 18, 259.

3. Lee, C. W.; Hong, D. H.; Han, S. B.; Jong, S.-H.; Kim, H. C.; Fine, R. L.; Lee, S.-H.; Kim, H. M. Biochem. Pharmacol. 2002, 64, 473.

4. Kim, S.; Park, J.-H.; Koo, S.-Y., Kim, J. I.; Kim, M.-H.; Kim, J. E.; Jo, K.; Choi, H. G.; Lee, S. B.; Jung, S.-H. J. Bioorg. Med. Chem. Lett. 2004, 4, 6075.

5. Bundgaard, H. In A Textbook of Drug Design and Development; Larsen, P. K., Bundgaard, H., Eds.; Harwood Academic: Switzerland, 1982; pp 1-39.

6. Bundgaard, H. Drugs of Fut. 1991, 16, 443.

7. Kearney, A. S.; Stella, V. J. Pharm. Res. 1992, 9, 497.

8. Rose, W. C. Anticancer Drugs 1992, 3, 311.

9. Safadi, M.; Oliyai, R.; Stella, V. J. Pharm. Res. 1993, 10, 1350.

10. Carey, F. A.; Giuliano, R. M. Organic Chemistry, 8th ed.; McGrawHill: 2010; pp 1134-1135.

11. Goolcharran, C.; Khossravi, M.; Borchardt, R. T. In Pharmaceutical Formulation Development of Peptide and Proteins; Frokjaer, S., Hovgaard, L., Eds.; Taylor and Francis, London, 2000; pp 70-88.

12. Casini, A.; Scozzafava, A.; Mincione, F.; Menabuoni, L.; Ilies, M. A.; Supuran, C. T. J. Med. Chem. 2000, 43, 4884.

13. http://webcache.googleusercontent.com/search?q=cache: VniKXVZiwgcJ:www.merckmanuals.com/professional/ clinical_pharmacology/pharmacokinetics/drug_absorption.html.

14. Skehan, P.; Storeng, R.; Scudiero, D.; Monks, A.; McMahon, J.; Vistica, D.; Warren, J. T.; Bokesh, H.; Kenney, S.; Boyd, M. R. J. Natl. Cancer Inst. 1990, 82, 1107. 